\title{
European Conference on Information Literacy (ECIL)
}

\author{
Serap Kurbanoğlu \\ Hacettepe University \\ Department of Information Management, Ankara, Turkey \\ kurbanogluserap@gmail.com
}

\begin{abstract}
The European Conference on Information Literacy (ECIL) aims to bring together researchers, information professionals, employers, media specialists, educators, policy makers and all the other related parties from around the world in order to exchange knowledge and experience and discuss recent developments and current challenges in and related to information literacy (IL). ECIL's mission is to provide an annual forum for individuals interested in IL, where they would share information about their research and practice. The first conference was organized by Hacettepe University, in Istanbul, Turkey, between 22-25 October 2013. The sixth conference is on its way. It will be hosted by the University of Oulu, Oulu, Finland, from 24-27 September 2018.

Both the international dimension and the research-practice nexus make ECIL different from the other IL-focused events in Europe. As an event rather than an organization, ECIL is also situated in the enviable position of not being subject to bylaws or structure that might restrict its focus or voice.
\end{abstract}

Keywords: information literacy, European Conference on Information Literacy (ECIL), mission, aim and scope, organization, annual forum, researchers, practitioners, Department of Information Management of Hacettepe University (Turkey), Department of Information and Communication Sciences of the University of Zagreb (Croatia)

\section{Introduction}

The number of conferences and publications dedicated to information literacy (IL) nowadays proves that it is an emerging topic. Satellite meetings of the Information Literacy Section of the International Federation of Library Associations and Institutions (IFLA) are examples of international IL conferences. The numerous conferences on this theme were held in America, Australia and New Zealand. Although there are a couple of conferences on IL held in Europe, such as LILAC in UK, Information Literacy Conference in Sibiu, Romania, and Creating Knowledge in Nordic countries, they are (though might not intended to be so) either limited by geographical scope - generally country or region oriented - or limited by the target group - information professionals or practitioners only. The idea of initiating an international annual conference that would be held in Europe, with an extended target group and strong research focus, was born to fill this gap.

\section{History of ECIL}

ECIL $^{1}$ is the result of dedication and efforts of two individuals (Serap Kurbanoğlu from the Department of Information Management of Hacettepe University, Turkey and Sonja Špiranec from the Department of Information and Communication Sciences of the University of Zagreb, Croatia) and support from numerous experts and institutions.

\footnotetext{
${ }^{1}$ ECIL, http://ilconf.org/ (accessed January 7, 2017).
} 
In 2008, UNESCO launched Training-the-Trainers in Information Literacy (TTT) project, coordinated by Woody Horton and Albert Boekhorst, which was composed of twelve regional workshops in various locations around the world. ${ }^{2}$ Within this project, Serap Kurbanoğlu hosted one of the regional workshops in Ankara, Turkey. Fifty people from 17 countries attended the workshop. Croatia, one of the participants, was represented by Sonja Špiranec. ${ }^{3}$ From that point on, Kurbanoğlu and Špiranec have met on a number of different occasions. Both were involved in the European Union Erasmus Intensive Program (IP) which took place at the University of Zagreb in September 2011. ${ }^{4}$ The idea of organizing an information literacy conference was born during this Erasmus IP, during a trip from Plitvice Lakes National Park to Zadar. The idea was to organize a truly international IL conference, to be held in Europe, with a strong research focus.

It took Kurbanoğlu and Špiranec two years for building the main structure of the conference - choosing a name; selecting the location and dates for the first conference; designing a logo; constructing the conference website; promoting the conference among potential target individuals and organizations; establishing conference committees by inviting experts from around the world.

The three main committees were built up. The Standing Committee's function was to act as an advisory board and help with the dissemination of the conference. Leading IL researchers and practitioners from as many countries as possible were included, to achieve international presence. The Programme Committee was built up from researchers in the field and its main function was to help with the review process. The Local Committee was to help with local organizational issues.

The Conference website was designed by Orçun Madran from Hacettepe University, who has acted as the webmaster thereafter. The logo was designed by Necip Erol Olcay, a former member of the Department of Information Management of Hacettepe University and designer of UNESCO Training-the-Trainers program. ECIL logo, featuring the stylized face of an owl, denotes wisdom.

\section{Aim and Scope}

ECIL aims to bring together researchers, information professionals, employers, media specialists, educators, policy makers and all the other related parties from around the world, to exchange knowledge and experience and discuss recent developments and current challenges in and related to IL.

ECIL's mission is to provide an annual forum for individuals interested in IL to share information about their research and practice. The call for participation invites broad exploration on the range of literacy (e.g., civic, data, digital, health, media copyright and visual), IL delivery (e.g., curricular design and e-learning), IL in specific settings (e.g., by type of library), IL training for information professionals, targeted IL (e.g., children and youth, and members of disadvantaged groups), to name a few topics. Starting from the third conference, calls to participate in ECIL have invited contributions on themes such as "Information Literacy in the Green Society" (2015), "Information Literacy in the Inclusive Society" (2016), "Workplace Information Literacy" (2017), and "Information Literacy in Everyday Life" (2018).

\footnotetext{
2 A. Boekhorst and F. W. Horton, "Training-the-Trainers in Information Literacy (TTT) Workshops Project, Final Report to UNESCO", The International Information \& Library Review 41 (4) (2009): 224-230.

${ }^{3}$ S. Kurbanoğlu, "Report of the UNESCO 'Training the Trainers in Information Literacy' ('TTT') Workshop Ankara, Turkey, September 3-5, 2008", International Information and Library Review 41 (4) (2009): 252-257.

${ }^{4}$ M. Banek-Zorica et al., Erasmus Intensive Programme: Information and Communication Technology in Supporting the Educational Process (2011), http://yunus.hacettepe.edu.tr/ tonta/yayinlar/tonta-zorica-erasmus-IP-programme.pdf (accessed January 7, 2017)
} 


\section{Organization}

Since 2013, ECIL has been co-organized by the Department of Information Management of Hacettepe University and the Department of Information and Communication Sciences of the University of Zagreb. Starting from 2017, InLitAs (Information Literacy Association) has become the third organizer. Each year, a Local Organizing Team assists in the organization.

Kurbanoğlu, Špiranec and Boustany (since 2017, the chair of InLitAs Joumana Boustany has joined the team) serve as co-chairs and are assisted by the three committees and an editorial team. The Standing Committee consists of about 130 members. Paul G. Zurkowski, who first coined the term "information literacy" in 1974, is the Honorary Chair of the Standing Committee. The Programme Committee, with nearly 100 people, assists the co-chairs by reviewing abstracts and full papers. The Local Organizing Committee takes care of logistics and local events.

The Editorial Team, which mainly consists of co-chairs of the conference, reviews and prepares abstracts books and proceedings. There is also a group of IL experts who are native speakers of the conference language (English), who act as the language editors (its current members are Esther Grassian, Diane Mizrachi and Loriene Roy). Apart from co-chairs and language editors, editorial team includes young researchers such as Denis Kos.

Since the very beginning, ECIL has been organized under the patronage of the two major organizations, UNESCO and IFLA, which have contributed tremendously to the development of IL. Additionally, each ECIL has supportive and sponsoring partners such as professional associations, government agencies, universities, LIS schools and commercial companies such as EBSCO and Thomson Reuters.

\section{Submission and Review Structure}

ECIL announces the conference, with the calendar and three calls for papers, on its website, about ten months prior to the conference date. Calls for papers are disseminated widely through various channels.

Submissions are required under different categories such as full papers, posters, PechaKucha (short presentations), best practices, doctoral forum, workshops, panels and special sessions. Each category has different requirements and restrictions regarding the length, time allocation and content.

Review process is double blind and runs in two cycles. Firstly, abstracts are required for all categories. They are peer-reviewed. Final copies of the accepted abstracts are published in the Abstracts Book. A conference management system is used for managing submissions and the review process. Secondly, full papers are required (only for paper and doctoral forum categories) and peerreviewed. Final copies of the accepted full texts are published in the Proceedings Book which is published by Springer under its CCIS (Communications in Computer and Information Science) series.

ECIL's writing guidelines and template are followed for writing abstracts, while Springer's guidelines and template are used for full papers.

\section{Programme Structure}

From its beginnings, ECIL has offered a robust and varied approach in sharing content over four days, starting with an opening session and a keynote presentation. Paul Zurkowski delivered the first keynote in 2013. The other keynote speakers were Christine Bruce and Indrajit Banerjee (Istanbul, 2013), David Bawden and Michael Eisenberg (Dubrovnik, 2014), Susan Danby, Carol Collier Kuhlthau and Sonja Livingstone (Tallinn, 2015), Tara Brabazon and Jan A. G. M. van Dijk (Prague, 2016), Bonnie Cheuk and Andrew Whitworth (Saint Malo, 2017) and Karen Fisher and Frans Mäyrä (Oulu, 2018). 
Each day of the conference features one or two invited speeches. Afterwards, parallel sessions start. Attendees choose a parallel session with papers grouped around a theme or sessions highlighting best practices. Workshops provide hands-on exploration of topics such as measuring IL competency or engaging youth in IL. Other programmes include panels for discussions on a selected topic, a doctoral forum on works done so far or on-going work of PhD students which provides an opportunity to gain valuable feedback from peers and subject specific experts, a poster session attended by all poster presenters, and PechaKucha which includes short and focused presentations, mostly about work in progress, fresh developments, innovations and good practices.

Social events include a welcome reception, gala dinner, and pre- and post-ECIL tours. At closing, a rapporteur summarizes the presentations, themes and discussions, and makes recommendations. Past rapporteurs included Ralph Catts, Bill Johnston, Sheila Webber, Stephane Goldstein and John Crawford. The closing ceremony ends with the announcement of the next year's venue and theme. A welcome speech is delivered by the next year's host.

\section{Conference Series}

The first conference was organized by Hacettepe University, at Harbiye Military Museum and Cultural Centre in Istanbul, Turkey, from 22-25 October 2013. The chair of the Local Committee was Serap Kurbanoğlu. The call for presentations for ECIL 2013 resulted in 396 submissions, 235 of which were accepted. The book of abstracts included 251 contributions, including a commentary, keynote and invited talks, as well as two earlier works including Zurkowski's report from 1974, where he first used the term IL. The number of conference participants was about 400.

The second conference was organized by the University of Zagreb. It was held at Hotel Valamar Lacroma in Dubrovnik, Croatia, from 20-23 October 2014. The chair of the Local Committee was Sonja Špiranec. 283 proposals were submitted to the conference and 165 were accepted.

The third conference was organized by the Institute of Information Studies of Tallinn University. It was held at Tallinn University, Tallinn, Estonia, from 19-22 October 2015. The chair of the Local Committee was Sirje Virkus. 226 proposals were submitted and 195 were accepted.

The fourth ECIL conference was co-organized and hosted by the Association of Libraries of Czech Universities - ALCU (Asociace knihoven vysokých škol - AKVŠ), at Orea Hotel Pyramida, Prague, Czech Republic, from 10-13 October 2016. The chair of the Local Committee was Hana Landova. 180 submissions were accepted and presented at the conference. ${ }^{5}$

The fifth conference was co-organized by the Information Literacy Association (InLitAs) and held in Saint-Malo, France, from 18-21 September 2017. The chair of the Local Committee was Joumana Boustany. 253 proposals were accepted.

The sixth conference is on its way. It will be hosted by the University of Oulu, at Hotel Lasaretti, Oulu, Finland, from 24-27 September 2018. The chair of the Local Committee is Maija-Leena Huotari.

\section{Participants and Impact}

Participants of the conference are mainly information professionals (both researchers and practitioners) from a variety of organizations. Each year, presenters come from nearly 60 different countries. Audience includes attendees from Asia, the Americas, Africa, Oceania, and Europe.

\footnotetext{
5 S. Webber, "ECIL Closing \#ecil2016." Information Literacy Weblog, October 13, 2016. http://information-literacy.blogspot.com/search/ label/ecil2016 (accessed January 7, 2017).
} 
The broad spectrum of information professionals, meeting in formal sessions and informal social venues, creates a fertile environment for international networking and collaborations. Some participants have formed research teams and initiate collaborative work.

There is some evidence that ECIL has resulted in an increase in publications about IL. Virkus analyzed citations of IL publications in Web of Science. ${ }^{6}$ She indicated that while "there were only few research IL publications" in the early 1990s, she counted 347 publications in 2013. She explained that nearly half ( 168 or 48 percent) of these publications resulted from the first ECIL.

Other outcomes noted in comments by attendees in conference evaluations, private conversations and blog posts, express the opinion that learning about IL developments, programmes, and research beyond their immediate situations has positively impacted their own work and agendas through the expansion of their perspectives and visions of IL. ECIL colleagues from Asia and Africa, recognizing the value of a regional conference with international participation, have expressed interest in developing their own local IL conferences. ${ }^{7}$

\section{Challenges and Future Plans}

ECIL emerged as a result of increased global attention given to IL. It has demonstrated that well organized efforts can lead to successfully delivered local events. ECIL is gaining recognition as an important information sharing venue and will continue to retain its name and logo, remaining the European Conference on Information Literacy. While increasingly international concerning attendance, the conference themes allow presenters to provide national, regional, and cross-border views on issues. Still, like any face-to-face event, ECIL faces challenges of extending its reach. IL has multifaceted aspects and implications that open possibilities for engagement beyond the LIS field, so ECIL is open to any attendee and provides multiple options for presenters. ECIL's main challenge is to attract the audience beyond the LIS profession, to include educators, media specialists, employers, policy makers, and others interested in the broad field of IL. Adoption of special conference themes such as green issues, inclusivity, and workplace literacy are efforts to expand both the audience and the focus of the conference, yet the impact of these efforts are, so far, uncertain. ECIL's future plans include addressing the challenge of involving different stakeholders. ${ }^{8}$

Another challenge is to keep the research focus strong, with the same participant pole, in annual intervals. Researchers have difficulties to come up with new research findings each year. Besides, it is hard to keep up with the work load on voluntary basis annually. This makes organizers to consider organizing it biennially in the future.

$E C I L$, as a relatively new event, plans to continue with its core vision which, for now, has proved to be successful: to be a truly global voice in IL and a platform to discuss IL from the widest possible range of perspectives from different parts of the world, different countries, and differing cultures. ECIL intends to continue serving as a meeting point for research and practice. Both the international dimension and the research-practice nexus make ECIL different from other IL-focused events in Europe. As an event rather than an organization, ECIL is also situated in the enviable position of not being subject to bylaws or structure that might restrict its focus or voice. ${ }^{9}$

\footnotetext{
${ }^{6}$ S. Virkus, "Knowledge Management and Information Literacy: An Exploratory Analysis", in Information Literacy: Key to an Inclusive Society, CCIS, vol. 676, S. Kurbanoğlu, et al. (eds) (Berlin: Springer, 2015), 119-132.

${ }^{7}$ L. Roy et al., "The European Conference on Information Literacy: An International Research-Practice Nexus", College and Research Libraries News, 78 (3) (2017): 131-134.

8 Ibid.

${ }^{9}$ Ibid.
} 
In 2016, ECIL organized an introductory preconference event as a participant-driven meeting about critical information literacy, the CIL Unconference. ${ }^{10}$ This experience is prompting us to consider introducing other fresh conference formats. This way, we hope to attract younger participants at the beginning of their research or professional careers, who might find such casual formats more attractive. ${ }^{11}$

What might serve ECIL best is to conduct a thorough evaluation of the attendance at the conference and its content, review of evaluations by attendees and rapporteur reports, as well as a citation analysis of the presented papers and published conference proceedings. Such an evaluation might also include comparison with other international IL conferences and, thus, result in mapping the global perspective of IL. This mapping might help to ascertain the potential, need and benefits of the future information sharing and collaboration. ${ }^{12}$

\section{References:}

1. Banek-Zorica, M., L. Amante, G. Bastos, S. Kurbanoğlu, S. Špiranec, Y. Tonta and V. Zabukovec. Erasmus Intensive Programme: Information and Communication Technology in Supporting the Educational Process. 2011. http://yunus.hacettepe.edu.tr/ tonta/yayinlar/tonta-zorica-erasmus-IP-programme.pdf (accessed January 7, 2017).

2. Boekhorst, A. and F. W. Horton. "Training-the-Trainers in Information Literacy (TTT) Workshops Project, Final Report to UNESCO". The International Information \& Library Review 41 (4) (2009): 224-230.

3. CIL Unconference. http://cilunconference.wixsite.com/home (accessed January 7, 2017).

4. ECIL. http://ilconf.org/ (accessed January 7, 2017).

5. Kurbanoğlu, S. "Report of the UNESCO 'Training the Trainers in Information Literacy' ('TTT') Workshop Ankara, Turkey, September 3-5, 2008". International Information and Library Review 41 (4) (2009): 252-257.

6. Roy, L., S. Kurbanoğlu, D. Mizrachi, and S. Špiranec. "The European Conference on Information Literacy: An International Research-Practice Nexus". College and Research Libraries News, 78 (3) (2017): 131-134.

7. Virkus, S. "Knowledge Management and Information Literacy: An Exploratory Analysis". In Information Literacy: Key to an Inclusive Society. CCIS, vol. 676. S. Kurbanoğlu, et al. (eds), 119-132. Berlin: Springer, 2015.

8. Webber, S. "ECIL Closing \#ecil2016." Information Literacy Weblog, October 13, 2016. http://informationliteracy.blogspot.com/search/label/ecil2016 (accessed January 7, 2017).

\footnotetext{
${ }^{10}$ CIL Unconference, http://cilunconference.wixsite.com/home (accessed January 7, 2017).

11 L. Roy et al., "The European Conference on Information Literacy: An International Research-Practice Nexus": 131-134.

12 Ibid.
} 


\section{Европска конференција о информационој писмености (ECIL)}

\section{Сажетак}

У раду је представљена Европска конференција о информационој писмености, која се од 2013. одржава као годишњи форум истраживача, информационих стручњака, библиотекара, наставника, теоретичара медија и новинара, креатора јавних политика и свих других заинтересованих из целог света. Мисија ECIL-a и јесте да обезбеди размену информација и искустава о проблемима везаним за информациону писменост, о текућим као и о будућим активностима појединаца или организација.

Ауторка текста, уз Соњу Шпиранец, идејни творац и организатор ове конференције, даје кратку историју ECIL-a, представља њену организацију, сумира податке о одзиву и учесницима, истиче строге критеријуме за рецензирање радова и престижне издаваче публикација, износи неке од организационих изазова и открива планове за будућност.

Прва конференција ECIL одржана је у Истанбулу (Турска) 22-25. октобра 2013, а организатор је био Одсек за информациони менаџмент Хачетепе универзитета из Анкаре. Друга је, годину дана касније, одржана у Дубровнику (Хрватска), а организатор је био Одсек за информационе и комуникационе науке Универзитета у Загребу. У току су припреме за шесту конференцију, чији је организатор Универзитет у Оулу, а која ће се одржати 24-27. септембра 2018. у Оулу (Финска).

Кључне речи: информациона писменост, Европска конференција о информационој писмености (ECIL), мисија, циљеви и задаци, организација, годишњи форум, истраживачи, практичари, Одсек за информациони менаџмент Хачетепе Универзитета (Турска), Одсек за информационе и комуникационе науке Универзитета у Загребу 


\section{(a) $(\mathbb{Q} \Theta \Theta$}

International License. 